\title{
RASIO KEKAKUAN LENTUR (FLEXURAL STIFFNESS RATIO) ELEMEN BETON AKIBAT GEMPA BERDASARKAN ANALISIS DINAMIK STRUKTUR SINGLE DEGREE OF FREEDOM (SDOF)
}

\author{
Widodo Pawirodikromo ${ }^{1, *)}$, Mas Anggit Arifudin ${ }^{2}$, Dewi Ayu Harjani ${ }^{3}$ \\ ${ }^{1, *}$ Jurusan Teknik Sipil, Fakultas Teknik Sipil dan Perencanaan, Universitas Islam Indonesia \\ Email: 785110201@uii.ac.id \\ ${ }^{2}$ Jurusan Teknik Sipil, Fakultas Teknik Sipil dan Perencanaan, Universitas Islam Indonesia \\ ${ }^{3}$ Jurusan Teknik Sipil, Fakultas Teknik Sipil dan Perencanaan, Universitas Islam Indonesia
}

\begin{abstract}
Modeling the effective stiffness of reinforced concrete elements for structural analysis is an important problem and needs to be solved. The effective stiffness is then expressed in terms of the average flexural stiffness ratio $C_{k}$. whose value has been determined by Codes. Previous studies have shown that the stiffness ratio is assumed/stated to be strength-dependent. Based on this statement, research on the flexural stiffness ratio $C_{k}$ of reinforced concrete elements through dynamic analysis of the SDOF structure was carried out. The SDOF structural model used has a vibration period $T=0.48 \mathrm{sec}$. The dynamic load used is 50 earthquake records consisting of 3groups of frequency content (low, moderate, high). The dynamic analysis that was carried out has accommodated the inelastic responses whose behavior follows Modified Takeda hysteretic loops. The study results showed that the maximum response of the structure generally occurred in the strong middle part of the earthquake recording or the period of the effective duration of D595. The main finding in this study is that the strength dependent of flexural stiffness is proven. The relationship between the average flexural stiffness ratio $C k$ and peak ground acceleration of $P G A$ can be mathematically expressed in the equation $C_{k}=-0.981 . P G A+0.822$. The relationship is negative, meaning that the higher the PGA value, the smaller the Ck value with a correlation coefficient of $R=0.635$ (moderate correlation). The $C_{k}$ value negatively correlates with the drift ratio and damage index, $D I$.
\end{abstract}

Keywords: Effective moment inertia, flexural stiffness ratio, plastic hinge, hysteretic loops, drift ratio, damage index

\section{PENDAHULUAN}

Sudah diketahui secara umum bahwa Indonesia adalah salah satu negara yang rawan terhadap bahaya gempa bumi. Hal tersebut sudah dibuktikan oleh kejadiankejadian gempa besar, sedang, maupun kecil di masa lampau. Gempa-gempa besar yang terjadi di Indonesia pada kurun waktu 25 tahun terakhir di antaranya adalah M9.0 gempa Aceh 2004, M8.6 gempa Nias 2005, M6.8 gempa Pangandaran 2006, M6.0 gempa Yogyakarta 2006, M7.6 gempa Padang 2009, M6.8 gempa Lombok 2018 dan M7.4 gempa palu 2018 (BMKG, 2018). Selain magnitude gempa $\mathrm{M}$, pada referensi tersebut juga disajikan korban manusia berikut kerugian akibat kerusakan bangunan, infrastruktur, dan lingkungan.

Menyadari begitu banyaknya korban manusia dan besarnya kerugian yang diakibatkan oleh bencana gempa bumi, maka Pemerintah Indonesia sangat berkepentingan untuk mengatur penyediaan bangunan, infrastruktur, dan pengendalian lingkungan terbangun melalui beberapa regulasi. Hal ini selaras dengan Peraturan Pemerintah Republik Indonesia Nomor 16 Tahun 2021 yang menyatakan bahwa penyediaan bangunan gedung harus dapat melindungi penghuninya secara aman dari segala bentuk 
pembebanan, termasuk didalamnya beban gempa sehingga terbangun Bangunan Tahan Gempa.

Untuk mewujudkan terbangunnya bangunan tahan gempa, maka diperlukan pedoman yang dipakai untuk keperluan perancangan dan saat pelaksanaan. Pedoman-pedoman tersebut kemudian distandarisasi oleh lembaga pemerintah nonkementerian yaitu Badan Standarisasi Nasional (BSN) sesuai dengan Undang-Undang Nomor 20 Tahun 2014 dan diterbitkan menjadi Standar Nasional Indonesia (SNI). Standar Nasional Indonesia SNI 1727-2013 adalah untuk beban hidup, SNI 1726-2019 untuk beban gempa, dan SNI 2847-2019 untuk desain elemen struktur. Standar-standar tersebut adalah standar yang paling sering digunakan untuk perencanaan bangunan tahan gempa.

Penentuan kebutuhan kekuatan (strength demand) merupakan langkah paling mendasar dan sangat penting dalam penyediaan bangunan tahan gempa. Untuk keperluan itu, hitungan beban gravitasi, beban gempa, kombinasi beban, pemodelan struktur, tahap tahapan analisis struktur, dan interpretasi hasil untuk keperluan kontrol kinerja respons struktur menjadi sesuatu tahapan yang sangat penting. Pada analisis struktur khususnya pada beban ultimit baik baban statik maupun dinamik, maka kekakuan elemen struktur harus dimodelkan sesuai dengan kemungkinan retak pada beton. Reta-retak pada beton akibat beban ultimit akan mengurangi momen inersia dari gross moment $I_{g}$ menjadi effective moment inertia, $I_{e}$. Berkurangnya momen inersia akan berpengaruh terhadap kekakuan elemen beton. Momen inersia efektif $\left(I_{e}\right)$ tersebut selanjutnya akan dipakai sebagai komponen dalam menentukan rasio kekakuan lentur (flexural stiffness ratio).

Penelitian tentang pengembangan momen inersia efektif $\left(I_{e}\right)$ untuk menentukan lendutan balok beton dengan tulangan konvensional dan fiber reinforced polymer (FRP) telah diteliti oleh Ammash dkk. Sejumlah sampel balok dengan panjang 2,0 $\mathrm{m}$ dan 2,5 $\mathrm{m}$ telah dipakai dan dibebani dengan single load, three point loads dan distributed load. Selain berdasarkan eksperimen, hasil penelitian juga diverifikasi dengan usulan formulasi numerik. Model formulasi numerik momen inersia efektif $\left(I_{e}\right)$ yang diajukan secara umum dapat memprediksi dengan baik lendutan balok hasil eksperimen di laboratorium. Elgohary dkk (2021) juga telah melakukan penelitian momen inersia efektif (Ie) dengan memakai variabel tinggi balok, tulangan tarik dan desak.

Sementara itu, Das dan Choudhury (2019) telah melakukan penelitian tentang pengaruh penggunaan momen inersia efektif terhadap kinerja struktur beton 3D untuk 12 tingkat. Dengan menggunakan displacement-based method (Calvi dkk., 2008), struktur MDOF kemudian ditransfer menjadi equivalent single degree of freedom (SDOF). Pada penelitian ini telah dipakai 3 variabel kekakuan yaitu gross stiffness $\left(I_{g}\right)$, stiffness as per FEMA 356 dan effective stiffness $\left(I_{e}\right)$, Inelastic Time History Analysis (THA) dengan 5 rekaman gempa telah dipakai, yang mana respons spektrumnya telah di skalakan (matching) dengan desain respons spektrum di lokasi bangunan. Hasil penelitian menunjukkan bahwa apabila dipakai gross stiffness akan menghasikan respons yang underestimates, rotasi sendi plastik yang kecil serta drif ratio sangat kecil dibandingkan dengan struktur yang menggunakan effective stiffness. Selain itu, respons struktur yang menggunakan kekakuan FEMA dinilai lebih realistik dibanding dengan struktur yang menggunakan gross stiffness. Penggunaan effective stiffness direkomendasikan untuk analisis struktur karena respons struktur yang diperoleh lebih rasional. Pada penelitian ini rasio kekakuan lentor langsung dipakai berdasarkan FEMA 356.

Penelitian terhadap efek penggunaan beberapa skenario/nilai flexural stiffness modification terhadap respons struktur beton bertingkat telah diteliti oleh Afsal (2018) dengan gedung yang dipakai sebagai model adalah bangunan dengan struktur rangka pemikul momen beton bertulang yang 
memiliki 7 tingkat. Struktur bangunan diasumsikan terletak di atas 2 jenis tanah yang berbeda yaitu di atas tanah jenis SB dan SD. Pada penelitian ini dipakai 4 skenario stiffness modifiaction yaitu: 1) SM-1, semua kekakuan struktur dimodel berdasarkan cracking stiffness; 2) SM-2 hanya slab yang memakai uncracked sementara struktur yang lain dipakai cracking stiffness; 3) SM-3 slab dan beams dimodel uncracked sementara struktur yang lain dipakai cracking stiffness dan 4) SM-4 adalah semua struktur dimodel uncracking stiffness. Secara singkat hasil analisis menunjukkan bahwa terhadap SM-4, respons SM-1 lebih besar secara signifikan untuk periode getar $\mathrm{T}$, simpangan horizontal $\mathrm{Y}$, simpangan antar tingkat (drift ratio) DR dan rotasi sendi plastik (plastic hinge rotation) PHR. Sementara itu respons yang lebih kecil adalah gaya geser dasar $\mathrm{V}$, momen guling (overturning moment) OM. Hasil tersebut rasional karena model SM-1 adalah struktur yang paling fleksibel sementara SM4 adalah struktur yang paling kaku. Resposns struktur untuk model SM-2 dan SM-3 berada diantaranya. Pada penelitian ini rasio kekakuan lentur juga langsung diambil berdasarkan FEMA 356.

Penelitian numerik tentang rasio kekakuan lentur akibat beban dinamik masih jarang dilakukan. Namun demikian penelitian ini masih dalam tahap awal, karena baru dilakukan di struktur SDOF akibat beban gempa. Hal ini dilakukan karena kekakuan elemen beton diduga/dinyatakan bersifat strength dependent yang berarti nilainya akan dipengaruhi oleh intensitas beban dan respons struktur (Das dan Choudhury, 2019). Rasio kekakuan lentur yang diperoleh berbeda dengan penelitian-penelitian di atas karena berasal dari analisis dinamik yang ditunjukkan oleh rata-rata sejarah kekakuan $\left(C_{k}\right)$ berdasar pada Modified Takeda hysteretic loops. Rasio kekakuan lentur yang diperoleh kemudian dikaitkan dengan gerakan tanah (acceleration, velocity dan displacement), nilai kandungan frekuensi (frequency contents) dan respons struktur (damage index dan hysteretic absorbsion energy). Pada penelitian berikutnya akan dilakukan di struktur bangunan bertingakat (Multi Degree of Freedom, MDOF).

\section{KEKAKUAN ELEMEN STRUKTUR BETON}

Kekakuan aksial (axial stiffness) dan kekakuan lentur (flexural stiffness) sangat sering dipakai pada analisis struktur, sementara itu kekakuan geser (sheat stiffness) pada umumnya dipakai pada dinamika tanah (soil dynamics). Sementara itu kekakuan torsi (torsion stiffness) banyak dipakai pada teknik mesin (mechanical engineering). Sebagai contoh, pada batang lentur, kekakuan lentur elastik $\mathrm{K}$ merupakan fungsi dari flexural rigidity $\left(E I_{g}\right)$ dan $L$ dimana $E$ adalah modulus elastik bahan, $\left(I_{g}\right)$ adalah momen inersia bruto potongan, dan $L$ adalah panjang batang. Apabila tidak ada rotasi pada ujung-ujung jepit balok, maka kekakuan lentur elastic shear building akibat perpindahan titik simpul/joint dapat dilihat pada Persamaan (1).

$$
K=\frac{12 \cdot E I_{g}}{L^{3}}
$$

Kekakukan (K) pada Persamaan (1) disebut sebagai kekakuan elastik shear building karena diasumsikan tidak ada rotasi pada ujung-ujung jepit balok/kolom. Kekakuan tersebut semata-mata terjadi akibat beban semi-statik $(P)$ atau $(V)$ yang masih relatif kecil, sehingga akan mengakibatkan simpangan elastik ujung batang sebesar $y$. Apabila beban semi-statik menjadi lebih besar, maka retak-retak pada elemen balok tidak dapat dihindari, sehingga momen inersia bruto $\left(I_{g}\right)$ akan berkurang menjadi momen inersia efektif $\left(I_{e}\right)$. Apabila modulus elastik (E) dan panjang batang tetap, maka kekakuan balok akan merupakan fungsi dari momen inersia efektif $\left(I_{e}\right)$ sebagaimana yang tertulis pada Persamaan (2).

$$
K=f\left(I_{e}\right)
$$

Selanjutnya terhadap momen inersia bruto dan momen inersia efektif, secara konseptual/ matematis rasio kekakuan lentur rata-rata 
(flexural stiffness ratio) $\left(C_{k}\right)$ dapat dinyatakan dalam Persamaan (3).

$$
C_{k}=\frac{K=f\left(I_{e}\right)}{K=f\left(I_{g}\right)},
$$

Rasio kekakuan lentur pada hakikatnya adalah rasio kekakuan elemen yang dihitung berdasarkan momen inersia efektif terhadap kekakuan elemen yang dihitung berdasarkan momen inersia bruto. Pada beberapa publikasi, rasio kekakuan lentur yang dinyatakan dalam notasi $\left(C_{k}\right)$ juga disebut sebagai flexural stiffness modification (Afsal, 2018).

Aysar dkk. (2014) dan ACI Committee (2014), telah menyajikan flexural stiffness ratio atau flexural stiffness modification dan segala modifikasinya yang khususnya untuk balok dan kolom sebagaimana disajikan pada Tabel 1. Secara umum, rasio kekakuan lentur $C_{k}$ juga akan dipenruhi oleh axial load ratio (Elwood dan Eberhard, 2006) (Miguel dan Santos, 2016).

\section{BEBAN GEMPA}

Pada penelitian ini dipakai rekaman 17 kejadian gempa di dunia yang meliputi gempa-gempa yang terjadi di Armenia (1 kejadian gempa, 1 rekaman), USA (10 kejadian gempa, 44 rekaman), Turki (1 kejadian gempa, 1 rekaman), Italia (1 kejadian gempa, 1 rekaman) Jepang (1 kejadian gempa, 1 rekaman), Taiwan (1 kejadian gempa, 1 rekaman), Yunani (1 kejadian gempa, 1 rekaman) dan Managua (1 kejadian gempa, 1 rekaman) yang diambil dari PEER Ground Motion Databases. Gempa-gempa tersebut semuanya adalah gempa dangkal (shallow crustal) akibat akitivitas sesar aktif. Gempagempa tersebut mempunyai percepatan maksimum (Peak Ground Acceleration) PGA $=0.175-0.503 \mathrm{~g}$.

Tabel 1. Rasio Kekakuan Lentur $\left(C_{k}\right)$ (Wong, 2016)

\begin{tabular}{|l|l|c|c|c|c|c|c|c|c|}
\hline \multirow{2}{*}{ No } & \multirow{2}{*}{ Elemen } & \multicolumn{7}{|c|}{ Rasio Kekakuan Lentur kr menurut beberapa sumber } \\
\cline { 3 - 10 } & & $\begin{array}{c}\text { ACI } \\
318-14\end{array}$ & $\begin{array}{c}\text { ASCE } \\
41-13\end{array}$ & $\begin{array}{c}\text { PEER } \\
\text { TBI }\end{array}$ & $\begin{array}{c}\text { LATBSD } \\
\text { C 2014 }\end{array}$ & $\begin{array}{c}\text { FEMA } \\
356\end{array}$ & $\begin{array}{c}\text { NZS } \\
3101\end{array}$ & $\begin{array}{c}\text { Euro } \\
\text { Code }\end{array}$ & $\begin{array}{c}\text { Paulay } \\
\text { Priestley }\end{array}$ \\
\hline 1 & Balok & 0,35 & 0,30 & 0,50 & 0,35 & 0,50 & 0,40 & 0,50 & 0,40 \\
\hline 2 & Kolom & 0,70 & 0,70 & 0,50 & 0,70 & 0,70 & 0,80 & 0,50 & 0,80 \\
\hline
\end{tabular}

Selain variasi nilai PGA, gempa yang dipakai juga sudah meperhitungkan variasi kandungan frekuensi (frequency Content) yang dinyatakan dalam Acceleration to Velocity Ratio atau $A / V$ ratio. Nilai $\mathrm{A} / \mathrm{V}$ ratio terbagi dalam 3-kelompok yaitu low frequency $\mathrm{A} / \mathrm{V}<0,8$ g.dt $/ \mathrm{m}$, medium frequency $0,8 \mathrm{~g} . \mathrm{dt} / \mathrm{m}<\mathrm{A} / \mathrm{V}<1.2 \mathrm{~m} . \mathrm{dt} / \mathrm{cm}$ dan high frequency $\mathrm{A} / \mathrm{V}>1,3 \mathrm{~m} . \mathrm{dt} / \mathrm{m}$ (Tso dkk., 1992). Nilai PGA dan kandungan frekeuensi gempa merupakan faktor utama yang akan berpengaruh pada respons struktur.

\section{RASIO KEKAKUAN LENTUR SECARA NUMERIK}

Struktur yang dipakai adalah stuktur dengan derajat kebebasan tunggal (Single Degree Of Freedom, SDOF). Model matematik untuk menggambarkan gaya inersia oleh gerakan massa $\mathrm{m}$ oleh gaya gempa dengan simpangan $y$ adalah seperti yang disajikan di Gambar 1 dan 2. Gerakan massa akan ditahan oleh kekakuan pegas $(k)$ (pemodelan kekakuan kolom) dam koefisien redaman (c). Karena beban gempa yang dipakai cukup banyak sebagaimana tertulis pada Tabel 1 , dengan percepatan tanah maksimum, durasi total gempa dan kandungan frekuensi bervariasi.

Apabila model struktur SDOF diguncang dengan beban-beban gempa tersebut, maka respons struktur tidak lagi bersifat elastik tetapi sudah mencapai respons inelastik. Respons inelastik akan mengakibatka berubah-ubahnya kekakuan batang yang sejarah kekakuannya akan membentuk hysteretic loops seperti yang disajikan di Gambar 2. Dong (2003) telah mengusulkan model hysteretik untuk batang lentur. Histeretic loops pada Gambar 2 adalah jenis modified Takeda atau Otani Model (Saiidi dan Sozen, 1979). 
Tabel 2. Daftar rekaman gempa yang dipakai

\begin{tabular}{|c|c|c|c|c|c|c|c|c|c|}
\hline $\begin{array}{l}\mathrm{N} \\
\mathrm{o} .\end{array}$ & \multicolumn{2}{|c|}{ Earthquake } & Record Ident. & Date & $\begin{array}{c}\text { Magni } \\
\text { Tude }\end{array}$ & $\begin{array}{c}\text { Compo } \\
\text { nent }\end{array}$ & $\begin{array}{c}\text { PGA } \\
(\mathrm{g})\end{array}$ & $\begin{array}{c}\mathrm{PGV} \\
(\mathrm{cm} / \mathrm{s})\end{array}$ & $\begin{array}{l}\text { PGD } \\
(\mathrm{cm})\end{array}$ \\
\hline 1 & 1 & Armenia & ErmeniaE & Dec., 7,1988 & 6.8 & 270 & 0.175 & 15.005 & 4.457 \\
\hline 2 & 2 & California & CalBent & Oct. 17,1989 & 6.9 & 270 & 0.209 & 27.097 & 11.259 \\
\hline 3 & \multirow{4}{*}{3} & Coyote Lake & CLakeClk & June 8, 1979 & 5.7 & 090 & 0.279 & 40.602 & 9.923 \\
\hline 4 & & Coyote Lake & CLakeGil & June 8, 1979 & 5.7 & 090 & 0.211 & 21.853 & 9.156 \\
\hline 5 & & Coyote Lake & CLakeGo2 & June 8, 1979 & 5.7 & 090 & 0.248 & 46.255 & 10.383 \\
\hline 6 & & Coyote Lake & CLakeGo3 & June 8,1979 & 5.7 & 090 & 0.272 & 37.345 & 13.685 \\
\hline 7 & \multirow{6}{*}{4} & Coalinga & CoalAntc & May 2,1983 & 6.4 & 270 & 0.33 & 32.209 & 4.788 \\
\hline 8 & & Coalinga & CoalChol & May 2,1983 & 6.4 & 090 & 0.136 & 9.078 & 1.385 \\
\hline 9 & & Coalinga & CoalCant & May 2,1983 & 6.4 & 270 & 0.227 & 23.615 & 5.751 \\
\hline 10 & & Coalinga & CoalFlt & May 2,1983 & 6.4 & 090 & 0.110 & 17.79 & 4.959 \\
\hline 11 & & Coalinga & CoalHc2 & May 2,1983 & 6.4 & 090 & 0.281 & 25.756 & 3.757 \\
\hline 12 & & Coalinga & CoalHz2 & May 2,1983 & 6.4 & 090 & 0.117 & 14.067 & 2.918 \\
\hline 13 & 5 & Corinth & Corinth & Feb. 24,1981 & 6.7 & 270 & 0.296 & 25.31 & 7.069 \\
\hline 14 & 6 & Izmit/Duzce & Duzce2E & Aug. 17,1999 & 7.6 & 090 & 0.257 & 16.312 & 7.459 \\
\hline 15 & \multirow{7}{*}{7} & Imp. Valley & EL40EWC & May 18,1940 & 6.9 & 270 & 0.215 & 29.229 & 27.491 \\
\hline 16 & & Imp. Valley & EL79Cal & Nov. 15,1979 & 6.6 & 225 & 0.275 & 42.414 & 35.069 \\
\hline 17 & & Imp. Valley & EL79Chi & Nov. 15,1979 & 6.6 & 282 & 0.254 & 30.079 & 12.478 \\
\hline 18 & & Imp. Valley & EL79Cpe & Nov. 15,1979 & 6.6 & 090 & 0.157 & 18.611 & 7.977 \\
\hline 19 & & Imp. Valley & EL79Sup & Nov. 15,1979 & 6.6 & 090 & 0.195 & 17.55 & 11.073 \\
\hline 20 & & Imp. Valley & EL79Crx & Nov. 15,1979 & 6.6 & 090 & 0.202 & 31.778 & 40.415 \\
\hline 21 & & Imp. Valley & EL79Shp & Nov. 15,1979 & 6.6 & 090 & 0.506 & 30.977 & 5.538 \\
\hline 22 & 8 & FriuliFoc & FriuliFocE & May 6, 1976 & 6.5 & 090 & 0.212 & 19.340 & 7.438 \\
\hline 23 & \multirow{2}{*}{9} & Hector Mine & HMHec & Oct. 16,1999 & 7.1 & 090 & 0.337 & 41.743 & 13.965 \\
\hline 24 & & Hector Mine & HMMngHm & Oct. 16,1999 & 7.1 & 090 & 0.173 & 17.172 & 11.123 \\
\hline 25 & 10 & Kobe & KobeNis & Jan. 17,1995 & 6.9 & 090 & 0.503 & 36.623 & 11.267 \\
\hline 26 & \multirow{6}{*}{11} & Loma Prieta & LPAndE & Oct. 17,1989 & 7.0 & 090 & 0.244 & 40.595 & 30.541 \\
\hline 27 & & Loma Prieta & LPCoE & Oct. 17,1989 & 7.0 & 090 & 0.386 & 30.974 & 20.225 \\
\hline 28 & & Loma Prieta & LPLobE & Oct. 17,1989 & 7.0 & 090 & 0.395 & 34.956 & 19.643 \\
\hline 29 & & Loma Prieta & LPGmrE & Oct. 17,1989 & 7.0 & 090 & 0.323 & 33.049 & 14.453 \\
\hline 30 & & Loma Prieta & LPGo2E & Oct.17,1999 & 7.0 & 090 & 0.192 & 25.383 & 22.697 \\
\hline 31 & & Loma Prieta & LPChiE & Oct q7,1999 & 7.0 & 090 & 0.269 & 20.86 & 2.36 \\
\hline 32 & 12 & Managua & Managua & Aug. 17,1972 & 5.7 & 090 & 0.421 & 21.301 & 5.694 \\
\hline 33 & \multirow{4}{*}{13} & Morgan Hill & MHillGo & April 24,1984 & 6.2 & 090 & 0.212 & 25.209 & 8.388 \\
\hline 34 & & Morgan Hill & MHillAnd & April 24,1984 & 6.2 & 090 & 0.423 & 50.547 & 18.25 \\
\hline 35 & & Morgan Hill & MHillGo2 & April 24,1984 & 6.2 & 090 & 0.224 & 38.637 & 17.167 \\
\hline 36 & & Morgan Hill & MHillHvr & April 24,1984 & 6.2 & 090 & 0.312 & 78.726 & 31.087 \\
\hline 37 & \multirow{4}{*}{14} & Mammoth Lk & MLakeCvk & May 27,1980 & 6.2 & 090 & 0.416 & 46.483 & 18.063 \\
\hline 38 & & Mammoth Lk & MLakeLul & May 27,1980 & 6.2 & 090 & 0.271 & 27.746 & 12.259 \\
\hline 39 & & Mammoth Lk & MLakeMLs & May 27,1980 & 6.2 & 090 & 0.321 & 31.413 & 6.236 \\
\hline 40 & & Mammoth Lk & MLakeMLs2 & May 27,1980 & 6.2 & 090 & 0.39 & 47.666 & 10.92 \\
\hline 41 & \multirow{3}{*}{15} & PalmSpring & PSpringCab & July 9,1986 & 6.0 & 090 & 0.213 & 32.644 & 8.879 \\
\hline 42 & & PalmSpring & PSpringDsp & July 9,1986 & 6.0 & 090 & 0.271 & 31.339 & 14.557 \\
\hline 43 & & PalmSpring & PSpringHo & July 9,1986 & 6.0 & 090 & 0.239 & 18.419 & 4.728 \\
\hline 44 & 16 & Taiwan86 & Taiwan86 & Nov.,14,1986 & 7.8 & 090 & 0.16 & 20.357 & 9.995 \\
\hline 45 & \multirow{6}{*}{17} & WNarrows & WNarAlh & Oct. 1,1987 & 6.1 & 090 & 0.326 & 43.932 & 9.667 \\
\hline 46 & & WNarrows & WNarBDam & Oct. 1,1987 & 6.1 & 130 & 0.313 & 28.937 & 3.079 \\
\hline 47 & & WNarrows & WNarCDam & Oct. 1,1987 & 6.1 & 130 & 0.221 & 17.48 & 2.569 \\
\hline 48 & & WNarrows & WNarEaton & Oct. 1,1987 & 6.1 & 090 & 0.151 & 11.448 & 1.994 \\
\hline 49 & & WNarrows & WNarFrem & Oct. 1,1987 & 6.1 & 270 & 0.414 & 32.594 & 9.283 \\
\hline 50 & & WNarrows & WNarAlt & Oct. 1,1987 & 6.1 & 090 & 0.151 & 11.448 & 1.994 \\
\hline
\end{tabular}




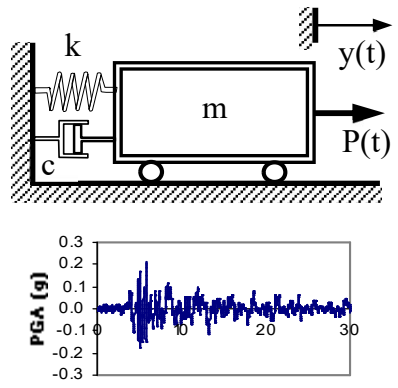

Gambar 1. Model matematik dan rekaman gempa

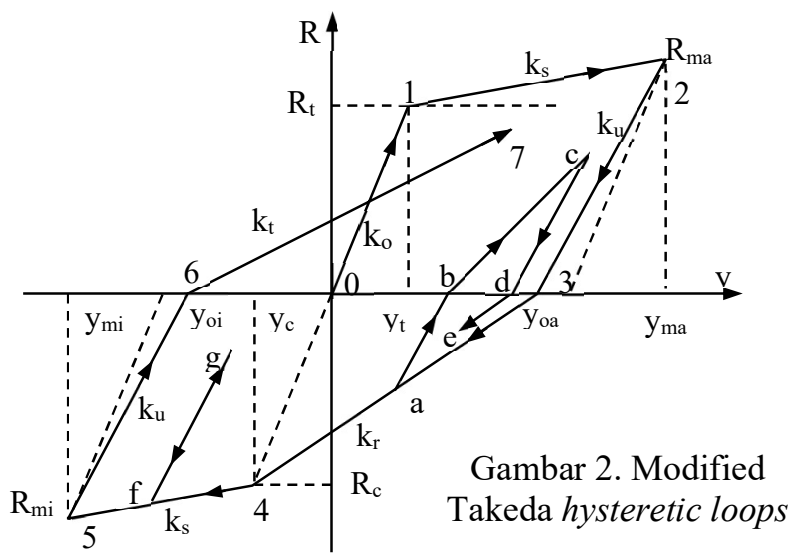

Gambar 2. Modified
Takeda hysteretic loops
Terhadap hysteretic loops tersebut, maka sejarah kekakuan batang akan melewati jalurjalur sebagai berikut

Jalur 1: kekakuan elastik $\left(k_{o}\right)$ mengikiti jalar $0-1$, yaitu manakala beban gempa masih kecil.

Jalur 2: kekakuan leleh, mengikuti jalur 1-2 dengan kekakuan $k_{s}=0,05 k_{o}$.

Jalur 3: kekakuan unlaoading mengikuti jalur 2-3 dengan kekakuan $k_{u}=\left(y_{t} / y_{m a}\right)^{0,5}$.

Jalur 4: kekakuan reloading, mengikuti jalur 3-4 dengan kekakuan $k_{r}=\mathrm{R}_{c} /\left(y_{c}+y_{o a}\right)$.

Jalur 5: suatu kemungkinan berbalik mengikuti jalur a-b-c-d-e.

Jalur 6: kekakuan leleh di simpangan negatif, mengikuti jalur 4-5, dengan $k_{s}=0,05 k_{o}$.

Jalur 7: kemungkinan berbalik dan mengikuti jalur $\mathrm{f}$-g.

Jalur 8: kekakuan unloading, mengikuti jalur 5-6 dengan $k_{u}=\left(y_{c} y_{m i}\right)^{0,5}$.

Jalur 9 :kekakuan realoading, mengikuti jalur 6-7 dengan $k_{t}=\mathrm{R}_{\mathrm{m}} /\left(y_{m a}+y_{o i}\right)$.

Kekakuan-kekakuan tersebut disajikan secara visual pada hysteretic loops seperti yang disajikan di Gambar 2. Karena struktur berupa inverted pandulum SDOF maka $\mathrm{k}_{\mathrm{o}}=3 \mathrm{EI} / \mathrm{h}^{3}$ yang mana $E I$ adalah flexural rigidity dan $h$ adalah tinggi struktur. Pada gambar tersebut tampak bahwa kekakuan tersebut nilainya selalu berubah-ubah sesuai dengan jalur yang dilewati berdasarkan intensitas beban gempa.
Karena kekakuan dapat bernilai maksimum $k_{o}$ kemudian dapat berdegradasi menjadi kekakuan minimum $k_{s}$ ataupun kekakuan di antaranya yaitu $k_{u}$ dan $k_{r}$, maka sejarah kekakuan di histeretic loops tersebut pada umumnya disebut fenomena stiffness degradation.

Nilai kekakuan elemen beton akan terhitung pada setiap langkah integrasi numerik dengan langkah integrasi $\Delta_{t}=0,01 d_{t}$. Apabila integrasi numerik mulai $i=1,2,3, \ldots, \mathrm{n}$, maka sebagai implementasi dari Persamaan (3) secara numerik akan diperoleh rasio kekakuan $r_{k l}, r_{k 2}, r_{k 3}, \ldots r_{k i}, r_{k n}$. Dengan demikian rasio kekakuan lentur rata-rata $C_{k}$ secara numerik dapat dihitung dengan Persamaan (4).

$$
C_{k}=\frac{\sum_{i=1}^{n} r_{k, i}}{n}
$$

Dimana $r_{k, i}$ adalah rasio kekakuan lentur pada langkah integrasi numerik ke-i dan $\mathrm{n}$ adalah jumlah langkah di integrasi numerik dan $C_{k}$ adalah rasio kekakuan lentur rata-rata.

Pada penelitian ini efek rasio kekakuan kekakuan lentur juga dikaitkan dengan beberapa parameter mulai dari ground acceleration, velocity, displacement, $\mathrm{A} / V$ ratio, hysteretic Energy dan element damage index, DI. Element damage index dihitung berdasarkan konsep yang diajukan oleh Park dan Ang (1985) yaitu Persamaan (5). 


$$
D I=\frac{d_{m}}{d_{u}}+\beta \frac{\int d E}{F_{y} \cdot d_{u}}
$$

Dimana $d_{m}$ dan $d_{u}$ maksimum dan simpangan ultimit, $\beta$ adalah cyclic degrading parameter, $F_{y}$ adalah gaya leleh, dan $E$ adalah disipasi hysteretic energy.

\section{METODE PENELITIAN}

\section{Model Struktur}

Pada penelitian ini model struktur yang dipakai masih relatif sederhana yaitu struktur tandon air dengan tinggi 3,50 $\mathrm{m}$ dan dengan asumsi bahwa massa air dianggap melekat (lumped mass) pada tandon. Dengan asumsi seperti itu, struktur dimodelkan hanya mempunyai derajat kebebasan tunggal (Single Degree of Freedom, SDOF). Bahan yang dipakai adalah beton bertulang dengan mutu $f^{\prime} c=255 \mathrm{~kg} / \mathrm{cm}^{2}$. Beban aksial ultimit kolom $P_{u}$ ditentukan sebesar 50 tf dan ukuran kolom adalah 40x55 cm dengan penulangan $2 \%$, maka column axial load ratio $P_{w} /\left(f^{\prime} c . A g\right)=$ 0,09 . Dengan demikian sebenarnya kolom akan lebih berperilaku seperti balok, atau dapat dikatakan didominasi oleh lentur (bukan didominasi oleh gaya aksial). Oleh karena itu hysteretic loops yang dipakai disesuaikan dengan perilaku lentur balok yaitu Modified Takeda atau Otani hysteretic model seperti yang disajikan pada Gambar 2. Dengan massa dan ukuran kolom tersebut maka periode getar struktut $T=0,48 \mathrm{dt}$. Model struktur kemudian digoncang/dibebani dengan percepatan tanah akibat gempa sebagaimana disajikan pada Tabel 1 . Nilainilai koefisien kekakukan pada hysteretic loops adalah seperti yang disajikan pada setiap jalur sebagaimana ditulis sbelumnya.

\section{Beban Gempa}

Beban gempa yang dipakai adalah seperti yang disajikan pada Tabel 1. Gempa-gempa tersebut dianggap merupakan rekaman percepatan tanah di level permukaan. Sebagaimana dikatakan sebelumnya bahwa kekakuan efektif elemen beton dinyatakan strength dependent artinya rasio kekakuan lentur akan bergantung pada intensitas beban (dalam hal ini percepatan tanah) dan respons struktur. Mengingat jumlah gempa yang dipakai cukup banyak, percepatan tanah maksimum cukup bervatiasi $(P G A=0,175$ $0,506 \mathrm{~g})$ dan dipakai 3-jenis earthquake frequency content (low, medium, high) maka diharapkan rasio kekakuan lentur juga relatif bervariasi. Rekaman gempa yang dipakai diambil dari situs.

\section{Computer Program}

Mengingat percepatan tanah akibat gempa yang dipakai sangat bervariasi, maka respons struktur tidak lagi bersifat elastik tetapi sudah mencapai respons inelastik. Pada fase initial weak part, intensitas gempa masih relatif kecil, kekakuan elemen masih elastik. Namun demikian pada fase middle strong part goncangan gempa akan mengakibatkan simpangan massa yang cukup besar sehingga elemen beton sudah memasuki fase leleh, kekakuan elemen menjadi sangat kecil. Pada fase final weak part, respon struktur kembali mengecil dan kekakuan elemen akan kembali membesar. Untuk dapat mengakomodasi perkembangan dan perubagan kekakuan elemen terseut maka dibuatkan program dinamik inelastik MTKDin. Dengan memakai program tersebut maka parameter-parameter respons inelastik struktur SDOF dapat dihitung.

\section{HASIL DAN PEMBAHASAN}

\section{Respons Time History}

Sebagaimana disampaikan sebelumnya bahwa pada tulisan ini rasio kekakuan lentur dihitung pada struktur SDOF yang dibebani dengan 50 rekaman gempa. Salah satu contoh rekaman percepatan tanah akibat gempa adalah seperti yang disajikan pada Gambar 3 . Pada gambar tersebut disajikan rekaman gempa Whittier Narrow USA 1 Oktober 1997 yang diberi kode rekaman WNarAlh (No 45 di Tabel 1). Gempa tersebut mempunyai percepatan tanah $0,326 \mathrm{~g}$ pada detik ke 6,21 dengan kecepatan tanah 43,932 $\mathrm{cm} / \mathrm{dt}$, sehingga mempunyai nilai $A / V$ ratio $=$ $0,742 \mathrm{~g} . \mathrm{dt} / \mathrm{m}$. Rekaman gempa tersebut 
termasuk low earthquake frequency content (Tso dkk., 1992). Rekaman gempa tersebut disajikan sebagai hasil karena akan dipakai sebagai referensi untuk hasil yang lain.

Sementara itu, Gambar 4 adalah sejarah simpangan horisontal massa struktur. Tampak pada gambar bahwa kandungan frekuensi getaran sudah lebih kecil daripada percepatan tanah di Gambar 3. Dapat diidentifikasi pula bahwa pola simpangan mengikuti pola percepatan tanah, dimana hal ini sudah sesuai dengan prinsip analisis dinamik. Simpangan maksimum percepatan tanah sebesar $y=7,05$ $\mathrm{cm}$ pada detik ke 10,61 . Ternyata simpangan maksimum tidak terjadi pada saat percepatan tanah maksimum. Dengan tinggi struktur 350 $\mathrm{cm}$, maka maksimum drift ratio $D R=2,01 \%$.

Pada Gambar 5 disajikan contoh sejarah kekakuan elemen beton selama pembebanan. Tampak pada gambar tersebut bahwa rasio kekakuan dinyatakan dalam momen inersia bruto Ig, sehingga pada saat elastik rasio kekakuan $r_{k}=1$. Pada gambar tersebut tampak respons elastik terjadi sejak awal sampai dengan detik ke 5,78 dengan $r_{k}=1$, dan setelahnya rasio kekakuan selalu berubahubah tergantung pada intensitas beban. Pada gambar 5 tersebut juga tampak rasio kekakuan lentur $C_{k}=0,404$ yang merupakan rata-rata dari sejarah kekakuan menurut Persamaan (4). Rasio kekakuan lentur tersebut dihitung berdasarkan respons struktur untuk semua beban 50 gempa yang dipakai.

Sementara itu pada Gambar 6 disajikan rasio sejarah kekakuan untuk 12 detik pertama. Gambar tersebut dipakai untuk mendeteksi kejadian sendi plastis yang ditunjukkan oleh rasio kekakuan minimum $r_{k}=0,05$ pada Gambar 6. Pada gambar tersebut tampak bahwa sampai dengan detik ke-5,59 nilai rasio kekakuan $r_{k}=1$ berarti kekakuan struktur masih bersifat elastik. Karena intensitas beban gempa masih relatif kecil maka periode ini pada umumnya disebut fase initial weak part. Setelah fase tersebut maka elemen struktur mulai leleh dan terjadilah sendi plastis. Jumlah kejadian dan durasi terjadinya sendi plastis adalah seperti yang disajikan pada Tabel 2.

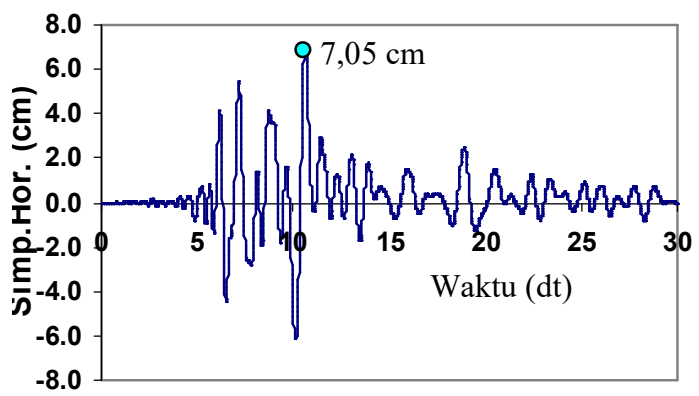

Gambar 4. Simpangan masa struktur

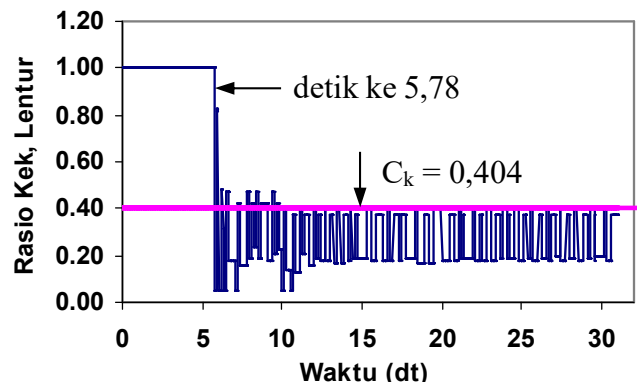

Gambar 5. Sejarak rasio kekakuan, $r_{\mathrm{k}}$

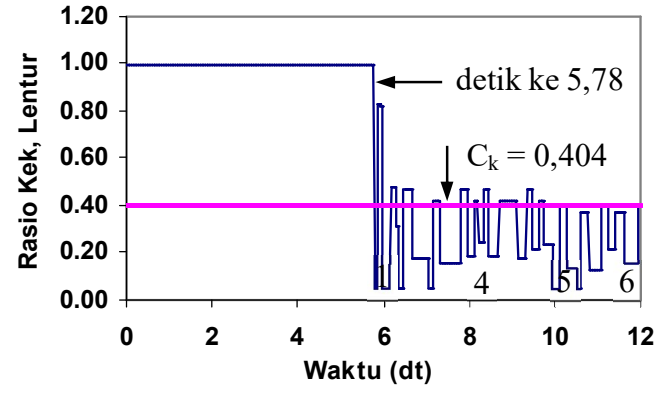

Gambar 6. Identifikasi sendi plastis 
Pada Gambar 6 dan Tabel 2 tersebut tampak bahwa terlah terjadi 6 kali sendi plastis yang dimulai pada detik ke 5,79 dan sendi plastis terakhir berakhir pada detik ke-10,60 saat terjadi simpangan maksimum. Durasi maksimum kejadian sendi plastis sangat singkat yaitu hanya $0,17 \mathrm{dt}$. Menurut Tabel 2 tersebut, mulai dari detik ke-5,59 sampai detik ke 10,50 pada umumnya disebut sebagai fase middle strong part. Setelah detik ke 10,60 respons struktur sudah memasuki fase final weak part.

Fase-fase pembebanan tersebut juga dapat dideteksi melalui penelusuran durasi efektif rekaman gempa. Gambar 7 adalah kurva durasi efektif gempa yang ditentukan berdasarkan konsep yang diajukan oleh Trifunac dan Brady (1975). Konsep tersebut banyak dipakai karena relatif sederhana dan relatf mampu menunjukkan durasi strong- part dari rekaman gempa. Durasi tersebut umumnya disingkat dengan $t_{e}$ atau kadangkadang disebut sebagai D595. Untuk menentukan durasi efektif dipakai rentang 5\% sampai dengan $95 \%$ nilai $\int a^{2} d t$ dalam $\mathrm{m} / \mathrm{dt}^{3}$ dimana a adalah percepatan tanah. Pada gambar tampak durasi efektif dimulai dari $t=$ $5,62 \mathrm{dt}$ dan berakhir pada $t=10,04 \mathrm{dt}$, sehingga $t_{e}=D 595=10,37 \mathrm{dt}$. Apabila diperhatikan, maka respons struktur maksimum dan rentang terjadinya sendi-sendi plastis berada pada rentang itu yaitu pada fase middle strong part sebagaimana disebut sebelumnya. Sementara itu, Gambar 8 adalah plot nilai Arias Intensity yang diperoleh melalui $I_{a}=\pi / 2 g \int a^{2} d t$ dalam m/dt. Tampak pada gambar bahwa plot Arias Intensity mirip dengan konsep durasi efektif karena keduanya mempunyai formulasi dasar yang sama.

Tabel 2. Kejadian dan durasi sendi plastis akibat gempa WNarAlt

\begin{tabular}{|c|c|c|c|c|}
\hline \multirow{2}{*}{$\begin{array}{l}\text { Kejadian sendi } \\
\text { plastis ke- }\end{array}$} & \multirow{2}{*}{$\begin{array}{c}\text { Rasio } \\
\text { kekakuan } \mathrm{r}_{\mathrm{k}}\end{array}$} & \multicolumn{2}{|c|}{ Detik ke } & \multirow{2}{*}{$\begin{array}{l}\text { Durasi } \\
\text { (dt) }\end{array}$} \\
\hline & & milai & berakhir & \\
\hline 1 & 0,05 & 5,79 & 5,84 & 0,05 \\
\hline 2 & 0,05 & 5,99 & 6,16 & 0,17 \\
\hline 3 & 0,05 & 6.35 & 6.47 & 0,12 \\
\hline 4 & 0,05 & 7,07 & 7,15 & 0,08 \\
\hline 5 & 0,05 & 9,98 & 10,10 & 0,02 \\
\hline 6 & 0,05 & 10,50 & 10,60 & 0,10 \\
\hline
\end{tabular}

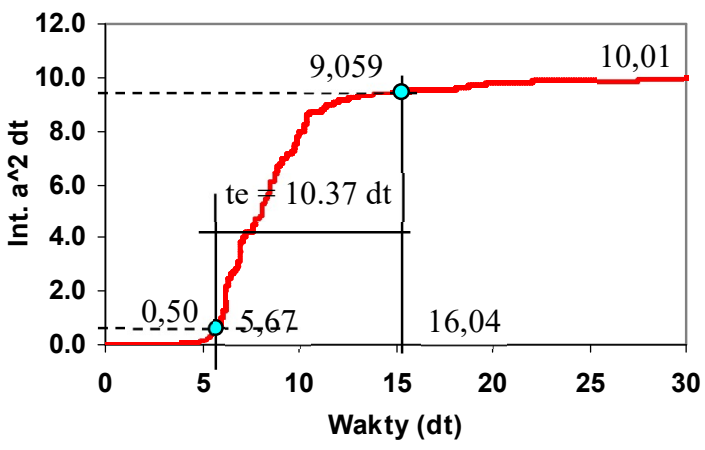

Gambar 7. Durasi efektif rekaman gempa

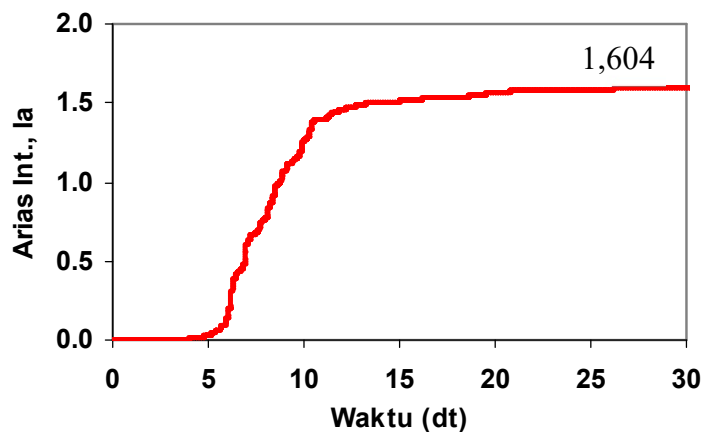

Gambar 8. Plot Arias Intensity 


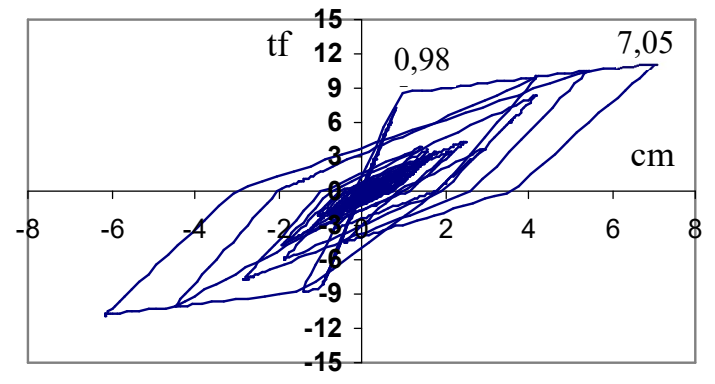

Gambar 9. Hysteretic loops

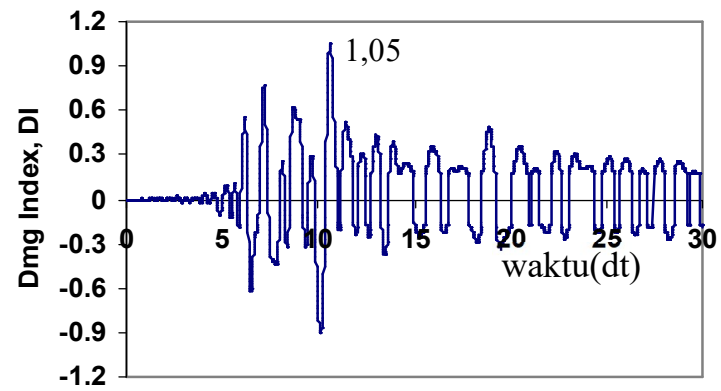

Gambar 10. Sejarah indeks kerusakan

\section{Hysteretic Loops dan Damage Index, DI}

Hysteretic loops pada hakekatnya adalah plot antara simpangan dengan gaya ataupun antara kurvatur/kelengkungan dengan momen. Hysteretic loops seperti yang disajikan pada Gambar 9. Gambar 9 adalah contoh plot antara simpangan $(\mathrm{cm})$ dengan gaya (tf) atas model struktur yang dipakai akibat rekaman gempa dengan kode WnarAlh sebagai mana disebut sebelumnya. Pada gambar tersebut tampak bahwa berdasarkan hitungan, gaya leleh $P_{y}=8,57 \mathrm{tf}$, simpangan leleh $y_{y}=0,98$ $\mathrm{cm}$ dan simpangan maksimum massa $y_{m}=$ $7,05 \mathrm{~cm}$. Pada hysteretic loops tersebut tercermin sejarah rasio kekakuan lentur yang nilainya ditunjukkan oleh kemiringan/slope garis-garis hysteretic loops. Rasio kekakuan lentur merupakan merupakan rata-rata dari rasio kekakuan.

Sementara itu, sejarah indeks kerusakan (damage index, DI) menurut Persamaan (5) dan disajikan pada Gambar 10. Sebagaimana disajikan di Persamaan (5), indeks kerusakan merupakan jumlah dari normalisasi deformasi dan serapan energi (Makhloof dkk., 2021). Dengan definiasi seperti itu maka tampilan sejarah indeks kerusakan tidak sama persis dengan sejarah simpangan seperti disajikan pada Gambar 4 tetapi masih dipengaruhi oleh serapan energi oleh struktur. Pada gambar tersebut tampak bahwa nilai maksimum indeks kerusakan DI $=1,05$ pada detik ke10,60. Hal ini berkesesuaian dengan kejadian sendi plastis sebagaimana disajikan pada Tabel 2. Dengan nilai indeks kerusakan

seperti itu maka sttruktur sudah sampai pada level rusak berat/runtuh (Makhloof dkk., 2021) (Li dkk., 2019).

\section{Rasio Kekakuan Lentur $C_{k}$}

Plot antara peak ground acceleration PGA atas 50 rekaman gempa yang dipakai (Tabel 1) lawan rasio kekakuan lentur $C_{k}$ disajikan pada Gambar 11. Tampak jelas pada gambar tersebut bahwa nilai $C_{k}$ terbukti bersifat strength dependent (Das dan Choudhury, 2019) artinya nilai $C_{k}$ sangat dipengaruhi oleh intensitas beban/percepatan tanah. Walaupun hasilnya agak menyebar tetapi tampak jelas bahwa semakin tinggi nilai PGA maka semakin kecil nilai $C_{k}$. Dengan demikian, antara PGA dan $C_{\mathrm{k}}$ mempunyai korelasi yang negatif dengan koefisien korelasi $R=0,687$. Dengan nilai $R$ tersebut hubungan anatar keduanya termasul moderate correlation (Schober dkk., 2018). Sebagai contoh PGA = 0,125 akan mengakibatkan $C_{k}=0,755$, selanjutnya pada $\mathrm{PGA}=0,533 \mathrm{~g}$ baru akan mengakibatkan nilai $C_{k}=0,35$ yaitu suatu nilai $C_{k}$ pada balok yang ditentukan oleh BSN, ACI, FEMA 356 (BSN, 2019) (ACI Committee 318, 2014) (FEMA 356, 2000). Tampak jelas bahwa nilai $C_{k}$ sangat dipengaruhi oleh nilai percepatan tanah atau bersifat strength dependent.

Sementara itu, plot antara PGV dengan $C_{k}$ disajikan pada Gambar 12. Senada dengan hasil sebelumnya, bahwa walaupun agak terpencar tetapi terdapat kecenderungan yang semakin kuat hubungan antara $P G V$ lawan $C_{k}$. Senada dengan hasil sebelumnya, antara 
keduanya berkorelasi secara negatif dengan koefisien korelasi $R=0,743$. Hal tersebut menunjukkan bahwa semakin besar $P G V$, maka semakin kecil rasio kekakuan lentur. Dengan nilai $R$ tesebut antara keduanya mempunyai hubungan yang bersifat strong correlation (Schober dkk., 2018).

Hasil-hasil tersebut dapat dikatakan sebagai finding pada penelitian ini, karena rasio kekakuan lentur berdasarkan analisis dinamik masih sangat jarang dilakukan oleh para peneliti. Pada penelitian yang disebut sebelumnya, rasio kekakuan lentur diperoleh dengan uji laboratorium balok sederhana dan bahkan pada penelitian yang lain nilai $C_{k}$ langsung diambil menurut nilai tertentu (FEMA 356, 2000) dan baru diperhitungkan dampaknya terhadap respons stuktur.

Pada Gambar 13 disajikan plot antara $P G D$ lawan $C_{k}$. Pada Gambar tersebut tampak senada dengan hasil-hasil sebelumnya yaitu antara $P G D$ dengan $C_{k}$ selain terpencar, hubungan antara keduanya semakin lemah. Hal ini ditunjukkan oleh nilai koefisien korelasi $R=0,362$ dengan hubungan yang besifat negatif. Dengan hasil-hasil tersebut, sementara dapat disimpulkan (khusus untuk model struktur ini) bahwa di antara parameter gerakan tanah, ternyata peak ground velocity $P G V$ mempunyai hubunngan yang paling kuat (strong correlation) dengan rasio kekakuan lentur rata-rata $C_{k}$.

Gambar 14 menyajikan sesuatu yang berbeda, yaitu hubungan antara earthquake ferquency content yang dinyatakan dalam $A / V$ ratio dengan rasio kekakuan lentur. Pada gambar tersebut tampak bahwa walaupun terpencar (dengan koefisien korelasi $R=0,189$ ) antara keduanya mempunyai hubungan yang positif, artinya semakin besar nilai $A / V$ ratio, maka rasio kekakuan lentur $C_{k}$ semakin tinggi pula.

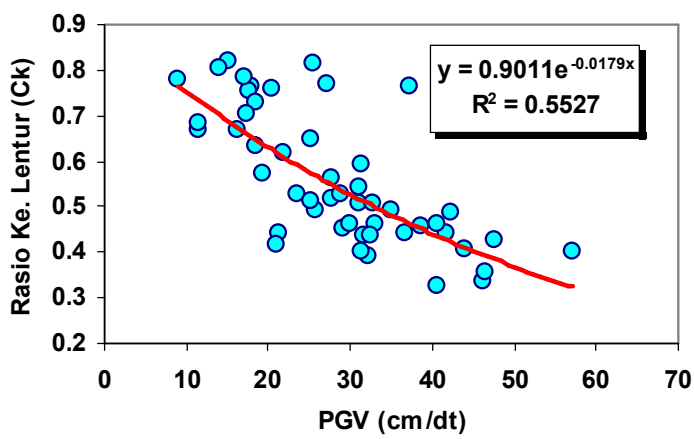

Gambar 12. Plot antara PGV lawan Ck

Gambar 11. Plot antara PGA dan $\mathrm{C}_{\mathrm{k}}$

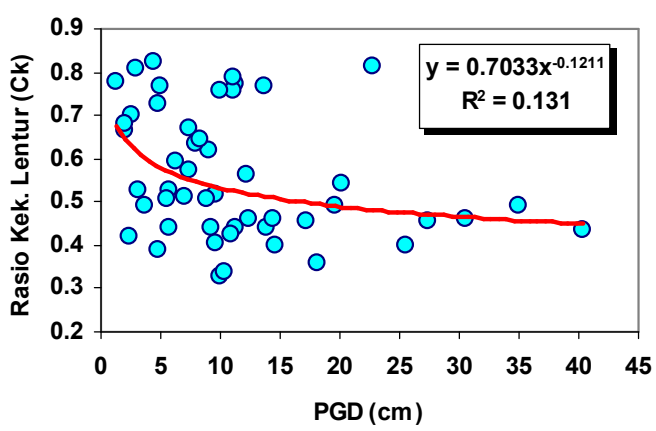

Gambar 13. Plot antara PGD dengan Ck
Gambar 14. Ploat A/V ratio dengan C

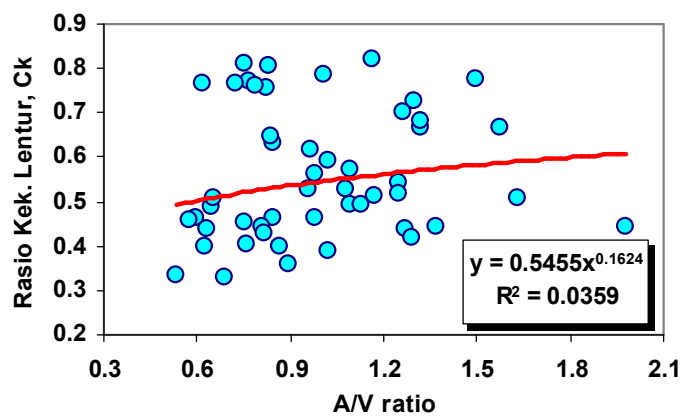


Dalam hal itu dapat dijelaskan bahwa semakin tingg $\mathrm{A} / \mathrm{V}$ ratio, maka suatu gempa akan mempunyai kandungan frekuensi yang semakin tinggi. Gambar 14 tersebut juga mempunyai arti bahwa model struktur yang dipakai relatif peka terhadap gempa dengan kandungan frekuensi rendah, sehingga rsemakin rendah $\mathrm{A} / \mathrm{V}$ ratio akan mengakibatkan nilai rasio kekakuan lentur $\mathrm{Ck}$ yang semakin rendah pula.

\section{Rasio kekakuan Lentur dan Respons Struktur}

Plot antara rasio kekakuan lentur dengan respons struktur yang dalam hal ini adalah drift ratio disajikan dalam Gambar 15. Tampak bahwa antara keduanya mempunyai hubungan yang negatif, artinya semakin besar $C_{k}$, nilai drift rasio semakin kecil. Hal ini wajar karena nilai $C_{k}$ yang relatif besar berarti kekakuan elemen masih relatif besar, sehingga simpangan massa dan drift ratio yang terjadi menjadi relatif kecil. Berdasarkan gambar tersebut, antara rasio kekakuan lentur $C_{k}$ dan drift ratio mempunyai koefisien korealsi $\mathrm{R}=0,897$, sehingga dimasukkan ke dalam kategori strong correlation (Schober dkk., 2018).

Sementara itu, hubungan antara rasio kekakuan lentur dan damage index DI disajikan pada Gambar 16. Senada dengan hasil-hasil sebelumnya, hubungan antara keduanya mempunyai korelasi negatif yaitu semakin besar nilai rasio kekakuan lentur, indeks kerusakan atau nilai damage index akan semakin kecil. Hal ini terjadi karena nilai $C_{k}$ yang tinggi itu berarti elemen struktur

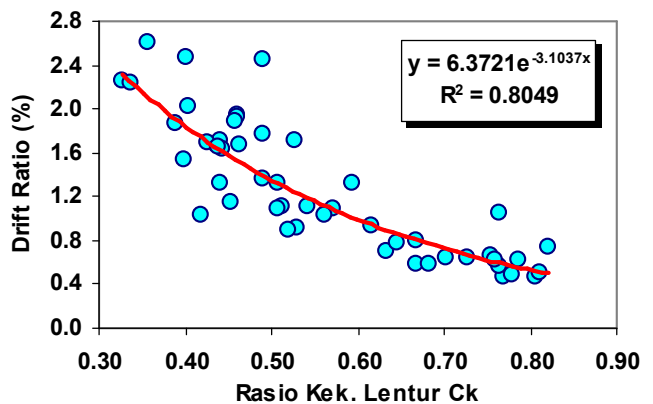

Gambar 15. Plot antara $C_{k}$ dengan drift ratio masih relatif kaku, simpangan massa menjadi relatif kecil, hystertic loops seperti yang ditunjukkan oleh Gambar 9 relatif kecil dan akhirnya indeks kerusakan seperti yang diformulasikan pada Persamaan (5) akan relatif kecil. Sebagaimana tampak pada gambar, hubungan antar keduanya mempunyai koefisien korelasi $\mathrm{R}=0,876$ dan hal itu berarti hubungan antara keduanya masuk dalam kategori strong correlation (Schober dkk., 2018).

\section{KESIMPULAN}

Penelitian tentang rasio kekakuan lentur ratarata $C_{k}$ telah dilakukan, yang pada tahap pertama ini baru terbatas pada struktur SDOF dan 1 model struktur dengan periode getar $T$ $=0,48 \mathrm{dt}$. Namun demikian, model struktur SDOF telah dibebani dengan 50 rekaman gempa dengan percepatan tanah yang relatif bervariasi. Analisis dinamik inelastik telah dilakukan dengan memakai Modified Takeda hysteretic loops untuk merepresentasikan respons inelastik struktur. Rasio kekakuan $r_{k}$ yang terjadi pada setiap hysteretic loops telah dipakai untuk menentukan rasio kekakuan lentur rata-rata $C_{k}$.

Berdasarkan respons inelastik, struktur yang dibebani oleh rekaman gempa WNarAlt telah dipakai sebagai contoh bahasan. Hasil yang diperoleh menunjukkan bahwa respons struktur maksimum baik simpangan, driftratio, indeks kerusakan (damage index, DI) maupun terjadinya sensi-sendi platis semuanya terjadi pada fase middle strong part rekaman gempa.

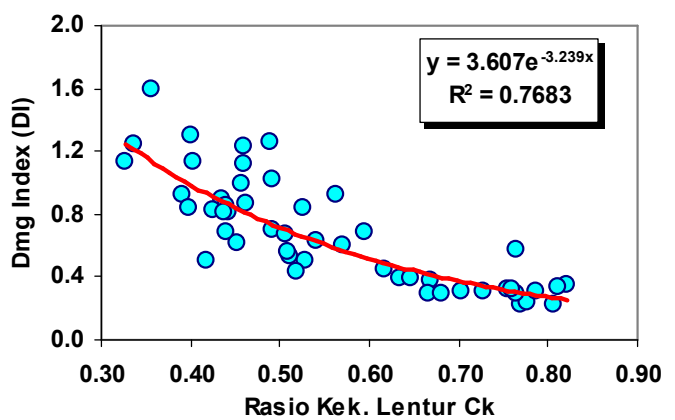

Gambar 16. Plot antara $C_{k}$ dengan DI 
Fase model strong part rekaman gempa juga berhasil diidentifikasi dengan baik melalui penelusuran durasi efektif $t_{e}$ atau D595. Sejarah rasio kekakuan $r_{k}$ (Gambar 5) dan hysteretic Loops (Gambar 9) selain dapat dipakai untuk menentukan rasio kekakuan lentur rata-rata, juga dapat dipakai untuk mengetahui kejadian-kejadian sendi plastis.

Temuan utama (finding) dari penelitian ini adalah diperolehnya bukti numerik bahwa rasio kekakuan lentur rata-rata adalah strength dependent, artinya nilai $C_{k}$ akan bergantung pada respons struktur atau bergantung pada peak ground acceleration PGA. Hubungan antara PGA dengan $C_{k}$ bersifat negatif, artinya semakin besar PGA, maka nilai $C_{k}$ akan semakin kecil. Pada penelitian ini juga diperoleh hasil bahwa antara PGA dan PGV dan $C_{k}$ mempunyai hubungan pada tingkat moderate to strong correlaton. Pada sisi yang lain earthquake frequency content yang dinyatakan dalam $A / V$ ratio mempunyai hubungan yang bersifat positif dengan $C_{k}$, walaupun dengan koefisien korelasi yang relatif kecil.

Hubungannya dengan respons struktur, rasio kekakuan lentur $C_{k}$ mempunyai hubungan yang bersifat negatif dengan drift ratio dan indeks kerusakan (damage index, DI) struktur. Hasil tersebut sangat logis, karena semakin besar $C_{k}$ berarti elemen struktur masih relatif kaku, dan kuat, sehingga drift ratio dan damage index semakin kecil. Namun demikian, masih disarankan bahwa untuk penelitian berikutnya pengaruh periode getar struktur $T$, jumlah tingkat pada struktur MDOF dan efek earthquake frequency content yang lebih komprehensif dan masih sangat diperlukan.

\section{DAFTAR PUSTAKA}

Afsal, S. (2018). Seismic Behavior of Multi Storied RC Frame Using Different Set of Stiffness Modification Factor. Islamabad: Master Thesis Capital University of Science and Technology.
American Concrete Institute. (2014). ACI 318-14 and ACI 318R-14: Building Code and Commentary Requirements for Structural Concrete. United States of America.

American Society of Civil Engineers. (2000). FEMA 356: Prestandard and Comentary for the Seismic Rehabilitation of Buildings. United States of America.

Ammash, H. K., Hemzah, H. A., \& AlRamahee, M. A. (2018). Unified Advanced Model of Effective Moment Inertia of Reinforced Concrete Members. International Journal of Applied Engineering Research, Vol.13, No.1, pp.557-562.

Avsar, O., Bayhan, B., \& Yakut, A. (2014). Effective flexural rigidity of ordinary reinforced concrete column and beams. The Structural Design of Tall and Special Buildings, Vol.23, pp.463-482.

BMKG. (2018). Katalog gempa bumi siknifikan dan merusak 1821-2018. Jakarta: Pusat gempa bumi dan tsunami Badan Meteorologi Klimatologi dan Geofisika.

BSN. (2013). SNI 1727-2013 tentang Beban Minimum untuk perancangan bangunan gedung dan yang lain, Standar Nasional Indonesia. Jakarta.

BSN. (2014). Undang-Undang Nomor 20 tahun 2014 tentang Standarisasi dan Penilaian Kesesuaian. Jakarta.

BSN. (2019). SNI 1726-2019 tentang Tata cara perencanaan ketahanan gempa untuk struktur bangunan gedung dan non gedung. Jakarta.

BSN. (2019). SNI 2847-2019 tentang Persyaratan beton struktural untuk bangunan gedung dan penjelasan. Jakarta.

Calvi, G. M., Priestley, M. J., \& Kowalsky, M. J. (2008). Earthquake Spectra. In Displacement Seismic Design of Structures.

Das, S., \& Choudhury, S. (2019). Influence of effective stiffness on the performance of RC buidings designed using 
displacement-based method and evaluation of column effective stiffness using ANN. Engineering Structures, Vol.197, 109354.

Dong, P. (2003). Effects of Varying Hysteretic Models and damage Models on Damage Assessment of Structures under Standard Design Level Earthquakes Obtained Using A New Scaling Methods. Christchurch, New Zealand: PhD Thesis University of Canterbury.

Elgohary, H., Osama, A. A., Badawi, M., \& Abduleazak, A. B. (2021). Non linear determination of the effective flexural rigidity of Reinforced concrete beams. International Research Journal of Engineering and Technology (IRJET), Vol.08, Issue 1, pp.164-168.

Elwood, K. J., \& Eberhard, M. O. (2006). Pacific Earthquake Engineering Research Center. Pacific Earthquake Engineering Research Center.

Li, Z., Chen, L., \& Teng, J. (2019). A Comparative test study on the seismic Damage Sustained by Frame Core Tube Structures. Advances in Engineering, Hindawi, Vol. 2019.

Makhloof D.A, I. A. (2021). Damage Assessment of Reinforced Concrete Structures through Damage Indices: A State of the Art Review. Computer Modeling in Engineering and Sciences.

Miguel, H., \& Santos, S. B. (2016). Seismic Analysis of Reinforced Concrete Structures Using Different Values of Stiffness. Technico Lisboa, University of Lisbon Portugal.

Park, Y. I., \& Ang, A. H. (1985). Mechanistic Seismic Damage Model for Reinforced Concrete. Journal of Structural Engineering, Vol.111, No.4, hal. 722-739.

Pawirodikromo, W. (2017). Analisis Dinamik Struktur. Yogyakarta: Pustaka Pelajar.

Peraturan Pemerintah RI. (2021). Peraturan Pemerintah Republik Indonesia No,
16 Tahun 2021 Tentang Peraturan Pelaksanaan Undang-Undang No.28 Tahun 2002 Tentang Bangunan Gedung. Jakarta.

Saiidi M, S. M. (1979). Simple and Complex Model for Nonlinear Seismic Response of Reinforced Concrete Structures. University of Illinois at Urbana-Champaign.

Schober, P., Boer, C., \& Schwarte, L. A. (2018). Correlation Coefficient: Appropriate use and Interpretation. Anesthesia and Analgesia, Vol. 126, No.5, pp.1763-1767.

Trifunac, M. D., \& Brady, A. G. (1975). A study on the duration of earthquake ground motion. Bulletin of the Seismological Society of America, Vol. 65, No.3, pp. 581-626.

Tso, W. K., Zhu, T. J., \& Heidebrecht, A. C. (1992). Engineering Application of Ground Motion A/V ratio. Soil Dynamics and Earthquake Eangineering, Vol.11, pp.133-144.

Wong, J. M. (2017). Effective Stiffness for Modeling Reinforce Concrete Structures. Retrieved from Structure Magazine: https://www.structuremag.org/?p=10 924 